\title{
Synthesis, characterization, and antibacterial studies of pipemidic acid metal complexes
}

\author{
Ahsan Zamir Siddiqi ${ }^{1,2}$ and Agha Zeeshan Mirza ${ }^{3^{*}}$
}

\begin{abstract}
Background: Pipemidic acid, like other quinolones, is susceptible against different organisms in vitro, and it was proved to be a preferred choice for certain indications. Previous studies reveal that concurrent administration of essential and trace elements with quinolones decreases gastrointestinal absorption, causing therapeutic failure. To study the probable interaction of pipemidic acid with essential and trace elements present in the human body, pipemidic acid has been reacted with magnesium, calcium, chromium, manganese, iron, cobalt, nickel, copper, zinc, and cadmium, the complexes formed.

Results: The compounds were characterized by the melting point, conductance studies, IR, UV, ${ }^{1} \mathrm{H}-\mathrm{NMR}$, CHN, and atomic absorption analysis.

Conclusion: The results suggested oxygen atoms present at carbonyl and carboxylic group render the bidentate6 property to the pipemidic acid. The antimicrobial activity of the compounds was determined by the disk diffusion method, and both standard and complexes show no antibacterial activity against the clinical isolates.
\end{abstract}

Keywords: Pipemidic acid, Metal complexes, Antibacterial studies

\section{Background}

Pipemidic acid (Fig. 1), an antibacterial agent [1], is found to be susceptible against different species of Escherichia, Proteus, Morganella, Citrobacter, Klebsiella, Enterobacter, Serratia, Pseudomonas aeruginosa, Pseudomonas cepacia, and other non-fermenting Gramnegative bacteria, while both Staphylococcus aureus and Staphylococcus epidermidis were 2 to 3 times less frequently susceptible to pipemidic acid and nalidixic acid than to norfloxacin and ofloxacin [2-4]. Pipemidic acid has an excellent inhibitory effect on caffeine by concomitant administration of pipemidic acid [5, 6]. Staib et al. [7] reported that pipemidic acid has markedly inhibited theophylline clearance. Pipemidic acid and its complexes have inhibitory action against Escherichia

\footnotetext{
* Correspondence: dr.zeeshan80@gmail.com

${ }^{3}$ Chemistry Department, Faculty of Applied Sciences, Umm Al-Qura

University, Makkah, Saudi Arabia

Full list of author information is available at the end of the article
}

coli, Bacillus subtilis, Streptococcus pneumonia, and Pseudomonas aeruginosa [8]. It is also showed some activity against Gram-positive bacteria. The basic piperazine ring, which can form the zwitterionic nature with the carboxylic acid at the C3-position, has subsequently been shown to increase the ability of the drugs to penetrate the bacterial cells resulting in enhanced activity. Further, the zwitterionic forms resulted in significant tissue penetration in pharmacokinetics [9]. Pipemidic acid is useful in different infections and inflammatory diseases as well as for prophylactic purposes. It is useful for infectious inflammatory diseases of the kidney, urinary tract, and prostate when given for 10 days twice daily in a dose of $400 \mathrm{mg}$ and has high efficacy against both Gram-negative and Gram-positive bacteria [10]. The interaction of metals with the drugs has significance in biological processes and drug effectiveness reliant on coordination with metals in many cases. The complexes of pipemidic acid with $\mathrm{Ca}^{2+}, \mathrm{Sr}^{2+}, \mathrm{Ba}^{2+}, \mathrm{Sn}(\mathrm{IV})$ [11] and

\section{Springer Open}

(c) The Author(s). 2021 Open Access This article is licensed under a Creative Commons Attribution 4.0 International License, which permits use, sharing, adaptation, distribution and reproduction in any medium or format, as long as you give appropriate credit to the original author(s) and the source, provide a link to the Creative Commons licence, and indicate if changes were made. The images or other third party material in this article are included in the article's Creative Commons licence, unless indicated otherwise in a credit line to the material. If material is not included in the article's Creative Commons licence and your intended use is not permitted by statutory regulation or exceeds the permitted use, you will need to obtain permission directly from the copyright holder. To view a copy of this licence, visit http://creativecommons.org/licenses/by/4.0/. 


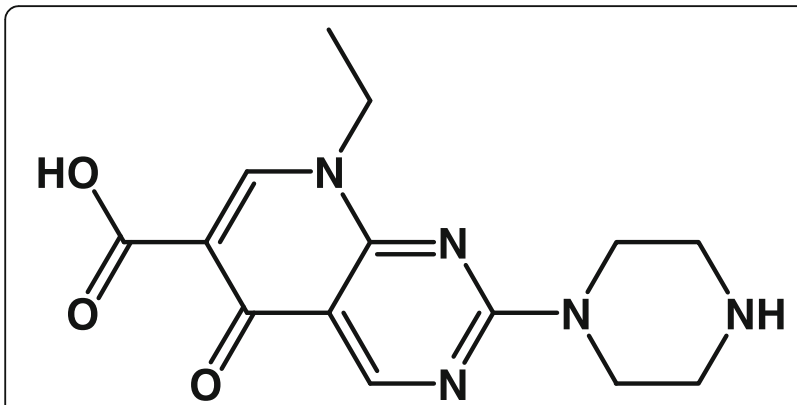

Fig. 1 Pipemidic acid

with $\mathrm{VO}^{2+}, \mathrm{Mn}^{2+}, \mathrm{Fe}^{3+}, \mathrm{Co}^{2+}, \mathrm{Ni}^{2+}, \mathrm{Zn}^{2+}, \mathrm{MoO}_{2}{ }^{2+}, \mathrm{Cd}^{2+}$, and $\mathrm{UO}_{2}{ }^{2+}$ are reported, and by utilizing the oxygen and carboxylate oxygen, it acts as a bidentate ligand [12]. In this paper, the synthesis and characterization of the complexes formed from the reaction of pipemidic acid with $\mathrm{Mg}(\mathrm{II}), \mathrm{Ca}(\mathrm{II}), \mathrm{Cr}(\mathrm{II}), \mathrm{Mn}(\mathrm{II}), \mathrm{Fe}(\mathrm{III}), \mathrm{Co}(\mathrm{II}), \mathrm{Ni}(\mathrm{II})$, $\mathrm{Cu}(\mathrm{II}), \mathrm{Zn}(\mathrm{II})$, and $\mathrm{Cd}(\mathrm{II})$ salts are reported and the comparative study of the effect of antibacterial activity of metal complexes against Gram-positive and Gramnegative strain of microorganisms.

\section{Method}

\section{Materials}

Pipemidic acid was kindly provided by Abbott Laboratories Pakistan. The essential and trace elements were used in the form of the following hydrated salts: magnesium chloride hexahydrate $\left(\mathrm{MgCl}_{2} \cdot 6 \mathrm{H}_{2} \mathrm{O}\right)$, calcium chloride dihydrate $\left(\mathrm{CaCl}_{2} \cdot 2 \mathrm{H}_{2} \mathrm{O}\right)$, chromium chloride hexahydrate $\left(\mathrm{CrCl}_{3} \cdot 6 \mathrm{H}_{2} \mathrm{O}\right)$, manganese chloride monohydrate $\left(\mathrm{MnCl}_{2}\right.$. $\left.\mathrm{H}_{2} \mathrm{O}\right)$, ferric chloride hexahydrate $\left(\mathrm{FeCl}_{3} \cdot 6 \mathrm{H}_{2} \mathrm{O}\right)$, cobalt chloride hexahydrate $\left(\mathrm{CoCl}_{2} \cdot 6 \mathrm{H}_{2} \mathrm{O}\right)$, nickel chloride hexahydrate $\left(\mathrm{NiCl}_{2} \cdot 6 \mathrm{H}_{2} \mathrm{O}\right)$, copper chloride dihydrate $\left(\mathrm{CuCl}_{2} \cdot 2 \mathrm{H}_{2} \mathrm{O}\right)$, zinc chloride $\left(\mathrm{ZnCl}_{2}\right)$, and cadmium chloride monohydrate $\left(\mathrm{CdCl}_{2} \cdot \mathrm{H}_{2} \mathrm{O}\right)$. Analytical grade methanol was used as a solvent.

\section{Synthesis}

The reported methods were used with slight modification $[13,14]$. Pipemidic acid trihydrate was dissolved in a little amount of DMF $(\sim 5 \mathrm{~mL})$, methanol was added $(20 \mathrm{~mL})$, and a solution of the metal in warm methanol $(10 \mathrm{~mL})$ was added with constant stirring. This solution was refluxed for $3 \mathrm{~h}$ and allowed to stand for crystallization at room temperature. Crystals obtained after $48 \mathrm{~h}$ were filtered and washed with methanol and dried. The melting point of these complexes was recorded on a Gallenkamp apparatus. The conductance of the complexes was measured by dissolving $0.003 \mathrm{~g}$ of the complex in $10 \mathrm{~mL}$ of distilled water. At the same time, the conductivity meter was calibrated with the help of $0.1 \mathrm{M}$ potassium chloride solution. These compounds were characterized by an IR spectrophotometer (Perkin
Elmer 1310 USA) in the region of $600-4000 \mathrm{~cm}^{-1}$. Spectrophotometric measurements were performed in the aqueous solution on a UV-visible (Shimadzu 240) spectrophotometer. Proton NMR studies were carried out on a Brucker instrument in deuterated water using TMS as an internal standard. Elemental analysis of carbon, hydrogen, and nitrogen was also employed using standard micro methods on Carlo Erba 1106. Metals were estimated on a Pye-Unicam atomic absorption spectrophotometer to determine the ratio of drug metal complexation.

\section{Results}

\section{Spectral data}

$\mathrm{C}_{28} \mathrm{H}_{34} \mathrm{~N}_{10} \mathrm{O}_{6} \mathrm{Mg}$ : colour, light brown; mp 280d; IR; 1620 b $(\mathrm{C}=\mathrm{O}), 1734 \mathrm{~m}(\mathrm{C}=\mathrm{O}$, ketone group), $2990 \mathrm{~m}(\mathrm{NH})$; $3400 \mathrm{~m}$ (OH stretch); ${ }^{1} \mathrm{H} \mathrm{NMR} ; 1.27\left(\mathrm{CH}_{3}\right.$, ethyl group), $\delta$ : $2.54\left(\mathrm{CH}_{2}\right.$, ethyl group), 2.79 and $3.30\left(2 \mathrm{CH}_{2}\right.$ of piperazinyl group), $3.88(\mathrm{H}$, ring position 5$), 8.87(\mathrm{H}$, ring position 2), 9.51 ( $\mathrm{H}$, carboxylic group); $\mathrm{C} ; \mathrm{H} ; \mathrm{N}$ found: C 53.34; $\mathrm{H}$ 5.40; N 22.26; M 3.85.

$\mathrm{C}_{28} \mathrm{H}_{34} \mathrm{~N}_{10} \mathrm{O}_{6} \mathrm{Ca}$ : colour, off white; mp 278d; IR; $1619 \mathrm{~s}$ ( $\mathrm{C}=\mathrm{O}), 1735 \mathrm{~s}(\mathrm{C}=\mathrm{O}$, ketone group), $2995 \mathrm{~m}(\mathrm{NH}), 3420$ m (OH stretch); ${ }^{1} \mathrm{H}$ NMR; $\delta$ : $1.34\left(\mathrm{CH}_{3}\right.$, ethyl group), $2.47\left(\mathrm{CH}_{2}\right.$, ethyl group), 2.84 and $3.32\left(2 \mathrm{CH}_{2}\right.$ of piperazinyl group), $3.93(\mathrm{H}$, ring position 5$), 8.84(\mathrm{H}$, ring position 2), $9.45(\mathrm{H}$, carboxylic group); $\mathrm{C} ; \mathrm{H} ; \mathrm{N}$ found: $\mathrm{C}$ 52.05; H 5.26; N 21.73; M 6.21.

$\mathrm{C}_{28} \mathrm{H}_{34} \mathrm{~N}_{10} \mathrm{O}_{6} \mathrm{Cr}$ : colour, greenish brown; mp 282d; IR; $1610 \mathrm{~s}(\mathrm{C}=\mathrm{O}), 1729 \mathrm{~s}$ ( $\mathrm{C}=\mathrm{O}$, ketone group), $2985 \mathrm{~m}$ (NH), $3430 \mathrm{~m}$ (OH stretch); ${ }^{1} \mathrm{H}$ NMR; $\delta: 1.29\left(\mathrm{CH}_{3}\right.$, ethyl group), $2.58\left(\mathrm{CH}_{2}\right.$, ethyl group), 2.87 and $3.27\left(2 \mathrm{CH}_{2}\right.$ of piperazinyl group), $3.90(\mathrm{H}$, ring position 5$), 8.82(\mathrm{H}$, ring position 2), 9.48 ( $\mathrm{H}$, carboxylic group); $\mathrm{C} ; \mathrm{H} ; \mathrm{N}$ found: C 51.11; H 5.23; N 21.35; M 7.88.

$\mathrm{C}_{28} \mathrm{H}_{34} \mathrm{~N}_{10} \mathrm{O}_{6} \mathrm{Mn}$ : colour, light yellow; mp 274d; IR; 1612 b $(\mathrm{C}=\mathrm{O}), 1732 \mathrm{sm}(\mathrm{C}=\mathrm{O}$, ketone group), $2983 \mathrm{~m}$ (NH), 3420 m (OH stretch); ${ }^{1} \mathrm{H}$ NMR; $\delta: 1.31\left(\mathrm{CH}_{3}\right.$, ethyl group), $2.56\left(\mathrm{CH}_{2}\right.$, ethyl group), 2.81 and $3.28\left(2 \mathrm{CH}_{2}\right.$ of piperazinyl group), 3.84 ( $\mathrm{H}$, ring position 5), $8.91(\mathrm{H}$, ring position 2), $9.50(\mathrm{H}$, carboxylic group); $\mathrm{C} ; \mathrm{H} ; \mathrm{N}$ found: C 50.79; H 5.22; N 21.21; M 8.31.

$\mathrm{C}_{28} \mathrm{H}_{34} \mathrm{~N}_{10} \mathrm{O}_{6}$ Fe: colour, orange; mp 220d; IR; 1605$1630 \mathrm{~b}(\mathrm{C}=\mathrm{O}), 1730 \mathrm{sm}(\mathrm{C}=\mathrm{O}$, ketone group), $2995 \mathrm{~m}$ $(\mathrm{NH}), 3440 \mathrm{~m}$ (OH stretch); ${ }^{1} \mathrm{H}$ NMR; $\delta: 1.28\left(\mathrm{CH}_{3}\right.$, ethyl group), $2.53\left(\mathrm{CH}_{2}\right.$, ethyl group), 2.81 and $3.28\left(2 \mathrm{CH}_{2}\right.$ of piperazinyl group), $3.84(\mathrm{H}$, ring position 5$), 8.91(\mathrm{H}$, ring position 2), 9.50 ( $\mathrm{H}$, carboxylic group); $\mathrm{C} ; \mathrm{H} ; \mathrm{N}$ found: C 50.80; H 5.23; N 21.20; M 8.43.

$\mathrm{C}_{28} \mathrm{H}_{34} \mathrm{~N}_{10} \mathrm{O}_{6} \mathrm{Co}$ : colour, light blue; mp 272d; IR; 1620 b $(\mathrm{C}=\mathrm{O}), 1732 \mathrm{~m}(\mathrm{C}=\mathrm{O}$, ketone group), $2983 \mathrm{~m}(\mathrm{NH})$, $3410 \mathrm{~m}$ (OH stretch); ${ }^{1} \mathrm{H}$ NMR; $\delta: 1.33\left(\mathrm{CH}_{3}\right.$, ethyl group), $2.48\left(\mathrm{CH}_{2}\right.$, ethyl group), 2.82 and $3.31\left(2 \mathrm{CH}_{2}\right.$ of piperazinyl group), $3.88(\mathrm{H}$, ring position 5$), 8.94(\mathrm{H}$, 
Table 1 Physical characteristics of pipemidic acid metal complex

\begin{tabular}{|c|c|c|c|c|c|}
\hline Drug complexed & Colour & Conductance $\mu \mathrm{s} / \mathrm{cm}$ & M.P ${ }^{\circ} \mathrm{C}$ & Change in $\varepsilon\left(\lambda_{\max }\right)$ & \\
\hline \multirow[t]{2}{*}{ Ref. drug } & Pale yellow & 57.1 & 252 & $39160(274)$ & $12269(314)$ \\
\hline & & & & $11575(330)$ & \\
\hline Magnesium & Light brown & 97.9 & $280 d$ & 36504 (276) & $11393(316)$ \\
\hline Calcium & Off white & 98.3 & $278 d$ & $35078(276)$ & $11256(317)$ \\
\hline Chromium & Greenish brown & 109.1 & $282 d$ & $26197(283)$ & $10998(335)$ \\
\hline Manganese & Light yellow & 90.9 & $274 d$ & 37687 (277) & $11791(316)$ \\
\hline Iron & Orange & 89.4 & $220 d$ & 31315 (276) & $10136(317)$ \\
\hline Cobalt & Light blue & 114.8 & $272 d$ & $29710(277)$ & 9265 (316) \\
\hline Nickel & Greenish white & 94.6 & $288 d$ & 49675 (277) & $15810(316)$ \\
\hline Copper & Brown & 118.7 & 230 & $39111(277)$ & $12143(317)$ \\
\hline Zinc & Off white & 128 & $278 d$ & 38184 (277) & 11952 (316) \\
\hline Cadmium & White & 111.2 & 266 & $33347(277)$ & $10677(316)$ \\
\hline
\end{tabular}

ring position 2), $9.46(\mathrm{H}$, carboxylic group); $\mathrm{C} ; \mathrm{H} ; \mathrm{N}$ found: C 50.50; H 5.20; N 21.06; M 8.88.

$\mathrm{C}_{28} \mathrm{H}_{34} \mathrm{~N}_{10} \mathrm{O}_{6} \mathrm{Ni}$ : colour, greenish white; mp 288d; IR; $1613 \mathrm{~s}(\mathrm{C}=\mathrm{O}), 1725 \mathrm{~m}$ ( $\mathrm{C}=\mathrm{O}$, ketone group), $2985 \mathrm{~m}$ (NH), $3390 \mathrm{~m}\left(\mathrm{OH}\right.$ stretch); ${ }^{1} \mathrm{H}$ NMR; $\delta: 1.29\left(\mathrm{CH}_{3}\right.$, ethyl group), $2.53\left(\mathrm{CH}_{2}\right.$, ethyl group), 2.87 and $3.32\left(2 \mathrm{CH}_{2}\right.$ of piperazinyl group), $3.89(\mathrm{H}$, ring position 5$), 8.90(\mathrm{H}$, ring position 2), $9.49(\mathrm{H}$, carboxylic group); $\mathrm{C} ; \mathrm{H} ; \mathrm{N}$ found: C 50.65; H 5.19; N 21.01; M 8.83.

$\mathrm{C}_{28} \mathrm{H}_{34} \mathrm{~N}_{10} \mathrm{O}_{6} \mathrm{Cu}$ : colour, brown; mp 230; IR; $1605 \mathrm{~m}$ $(\mathrm{C}=\mathrm{O}), 1724 \mathrm{~m}(\mathrm{C}=\mathrm{O}$, ketone group $), 2990 \mathrm{~m}(\mathrm{NH})$, $3380 \mathrm{~m}$ (OH stretch); ${ }^{1} \mathrm{H}$ NMR; $\delta: 1.34\left(\mathrm{CH}_{3}\right.$, ethyl group), $2.49\left(\mathrm{CH}_{2}\right.$, ethyl group), 2.87 and $3.30\left(2 \mathrm{CH}_{2}\right.$ of piperazinyl group), $4.0(\mathrm{H}$, ring position 5), $8.96(\mathrm{H}$, ring position 2), 9.56 ( $\mathrm{H}$, carboxylic group); $\mathrm{C} ; \mathrm{H} ; \mathrm{N}$ found: $\mathrm{C}$ 50.11; H 5.15; N 20.83; M 9.50.

$\mathrm{C}_{28} \mathrm{H}_{34} \mathrm{~N}_{10} \mathrm{O}_{6} \mathrm{Zn}$ : colour, off white; mp 278d; IR; 1618 $\mathrm{m}(\mathrm{C}=\mathrm{O}), 1730 \mathrm{~m}(\mathrm{C}=\mathrm{O}$, ketone group), $2985 \mathrm{~m}(\mathrm{NH})$,
$3420 \mathrm{~m}$ (OH stretch); ${ }^{1} \mathrm{H}$ NMR; $\delta: 1.36\left(\mathrm{CH}_{3}\right.$, ethyl group), $2.57\left(\mathrm{CH}_{2}\right.$, ethyl group), 2.85 and $3.26\left(2 \mathrm{CH}_{2}\right.$ of piperazinyl group), $3.82(\mathrm{H}$, ring position 5$), 8.85(\mathrm{H}$, ring position 2), $9.53(\mathrm{H}$, carboxylic group); $\mathrm{C} ; \mathrm{H} ; \mathrm{N}$ found: C 50.10; H 5.12; N 20.90; M 9.72.

$\mathrm{C}_{28} \mathrm{H}_{34} \mathrm{~N}_{10} \mathrm{O}_{6} \mathrm{Cd}$ : colour, white; mp 266; IR; $1600 \mathrm{~b}$ $(\mathrm{C}=\mathrm{O}), 1720 \mathrm{~m}(\mathrm{C}=\mathrm{O}$, ketone group), $2980 \mathrm{~m}(\mathrm{NH})$, 3440 b (OH stretch); ${ }^{1} \mathrm{H}$ NMR; $\delta: 1.31\left(\mathrm{CH}_{3}\right.$, ethyl group), $2.55\left(\mathrm{CH}_{2}\right.$, ethyl group), 2.80 and $3.29\left(2 \mathrm{CH}_{2}\right.$ of piperazinyl group), $3.92(\mathrm{H}$, ring position 5$), 8.89(\mathrm{H}$, ring position 2), $9.59(\mathrm{H}$, carboxylic group); $\mathrm{C} ; \mathrm{H} ; \mathrm{N}$ found: C 46.71; H 4.74; N 19.53; M 15.62.

\section{Antibacterial studies}

Antibacterial studies of pipemidic acid metal complexes against Gram-positive and Gram-negative organisms, such as Klebsiella Pneumoniae, Proteus mirabilis, Staphylococcus aureus, Corynebacterium hoffmanni,

Table 2 Infrared absorption bands shifting of pipemidic acid metal complexation

\begin{tabular}{llll}
\hline Drug complex with & $\mathbf{O}-\mathbf{H}$ stretch & Carboxylic acid C = O & Pyridone ring C = O (ketone) \\
\hline Reported drug & 3465 & 1640 & 1619 \\
Ref. drug & $3460 \mathrm{~b}$ & $1640 \mathrm{~m}$ & $1620 \mathrm{~m}$ \\
Magnesium & $3400 \mathrm{~m}$ & $1620 \mathrm{~b}$ & $1734 \mathrm{~m}$ \\
Calcium & $3420 \mathrm{~b}$ & $1619 \mathrm{~s}$ & $1735 \mathrm{~s}$ \\
Chromium & $3430 \mathrm{~b}$ & $1610 \mathrm{~s}$ & $1729 \mathrm{~s}$ \\
Manganese & $3420 \mathrm{~b}$ & $1612 \mathrm{~b}$ & $1732 \mathrm{sm}$ \\
Iron & $3440 \mathrm{~b}$ & $1605-1630 \mathrm{~b}$ & $1730 \mathrm{sm}$ \\
Cobalt & $3410 \mathrm{~b}$ & $1620 \mathrm{~b}$ & $1732 \mathrm{~m}$ \\
Nickel & $3390 \mathrm{~b}$ & $1613 \mathrm{~s}$ & $1725 \mathrm{~m}$ \\
Copper & $3380 \mathrm{~b}$ & $1605 \mathrm{~m}$ & $1724 \mathrm{~m}$ \\
Zinc & $3420 \mathrm{~b}$ & $1618 \mathrm{~m}$ & $1730 \mathrm{~m}$ \\
Cadmium & $3440 \mathrm{~b}$ & $1600 \mathrm{~b}$ & $1720 \mathrm{~s}$ \\
\hline
\end{tabular}


Table 3 Proton NMR assignments of pipemidic acid and its metal complexes

\begin{tabular}{|c|c|c|c|c|c|c|c|}
\hline \multirow{2}{*}{$\begin{array}{l}\text { Drug } \\
\text { complexed } \\
\text { with }\end{array}$} & \multicolumn{2}{|c|}{ Ethyl group } & \multicolumn{2}{|c|}{ Piperazinyl group } & \multirow{2}{*}{$\begin{array}{l}\text { Ring } \\
\text { proton } \\
\text { of } \\
\text { position } \\
2\end{array}$} & \multirow{2}{*}{$\begin{array}{l}\text { Ring } \\
\text { proton } \\
\text { of } \\
\text { position } \\
5\end{array}$} & \multirow[t]{2}{*}{ Carboxylic } \\
\hline & $\overline{\mathrm{CH}_{2}}$ & $\mathrm{CH}_{3}$ & $\overline{\mathrm{CH}_{2}}$ & $\mathrm{CH}_{2}$ & & & \\
\hline Reference drug & 2.47 & 1.34 & 2.77 & 3.33 & 8.94 & 3.81 & 9.17 \\
\hline Magnesium & 2.54 & 1.27 & 2.79 & 3.30 & 8.87 & 3.88 & 9.51 \\
\hline Calcium & 2.47 & 1.34 & 2.84 & 3.32 & 8.84 & 3.93 & 9.45 \\
\hline Chromium & 2.58 & 1.29 & 2.87 & 3.27 & 8.82 & 3.90 & 9.48 \\
\hline Manganese & 2.56 & 1.31 & 2.81 & 3.28 & 8.91 & 3.84 & 9.50 \\
\hline Iron & 2.53 & 1.28 & 2.84 & 3.27 & 8.87 & 3.87 & 9.52 \\
\hline Cobalt & 2.48 & 1.33 & 2.82 & 3.31 & 8.94 & 3.88 & 9.46 \\
\hline Nickel & 2.53 & 1.29 & 2.87 & 3.32 & 8.90 & 3.89 & 9.49 \\
\hline Copper & 2.49 & 1.34 & 2.87 & 3.30 & 8.96 & 4.00 & 9.56 \\
\hline Zinc & 2.57 & 1.36 & 2.85 & 3.26 & 8.85 & 3.82 & 9.53 \\
\hline Cadmium & 2.55 & 1.31 & 2.80 & 3.29 & 8.89 & 3.92 & 9.59 \\
\hline
\end{tabular}

Klebsiella species, Shigella dysentery, Streptococcus faecalis, Corynebacterium diphtheria, Escherichia coli, Pseudomonas aeruginosa, Bacillus species, Citrobacter species, Salmonella typhi, and Streptococcus pyogenes were carried out by disk susceptibility technique. The diffusion technique, according to FDA, was followed used widely in clinical laboratories [15-17].

\section{Discussion}

The solubility of pipemidic acid complexes was checked in different solvents; all complexes were stable at room temperature and were soluble in water. The conductance of all complexes was then measured by dissolving $3 \mathrm{mg}$ of complexes in $10 \mathrm{~mL}$ water; pipemidic acid was also prepared in the same manner having $24 \mu \mathrm{s} / \mathrm{cm}$. The conductance of all metal complexes markedly increased compared to the reference drug. The melting point of reference drugs and complexes was also studied. Pipemidic acid reference standard was melted at $252^{\circ} \mathrm{C}$, but most of its metal complexes were decomposed. The physical characteristics of pipemidic acid and its metal complexes are shown in Table 1.

\section{IR spectroscopy}

IR spectrum of the pipemidic acid showed two strong bands at $1619 \mathrm{~cm}^{-1}$ and $1640 \mathrm{~cm}^{-1}$, which were assigned to the stretching vibration of the carboxylic carbonyl group and ring carbonyl group, respectively [18], whereas in our spectra of pipemidic acid for $\mathrm{CO}$ of carboxylic carbonyl group was found at $1620 \mathrm{~cm}^{-1}$ as the medium peak, $\mathrm{CO}$ of the ring carbonyl group (ketone) lied at $1640 \mathrm{~cm}^{-1}$, and for $\mathrm{OH}$, the absorption was at $3460 \mathrm{~cm}^{-1}$ as a medium peak. Lin et al. [18] reported complexes of pipemidic acid with rare earth metals. They found a $1717-1737 \mathrm{~cm}^{-1}$ band, which shows the coordination of metal ions with $\mathrm{OH}$ of the carboxylic group. The shift to a higher frequency of carboxylic group takes place due to complexation with water of crystallization. The $\mathrm{C}=\mathrm{O}$ ring and $\mathrm{OH}$ in the carboxylic group were shifted to a lower frequency, and the same results were obtained in our studies of all metal complexes with pipemidic acid.

In all metal complexes, the peak of the carboxylic group was shifted to a higher frequency. In magnesium, cobalt, nickel, copper, and zinc, the peak shift was observed between 1724 and $1734 \mathrm{~cm}^{-1}$ as a medium peak

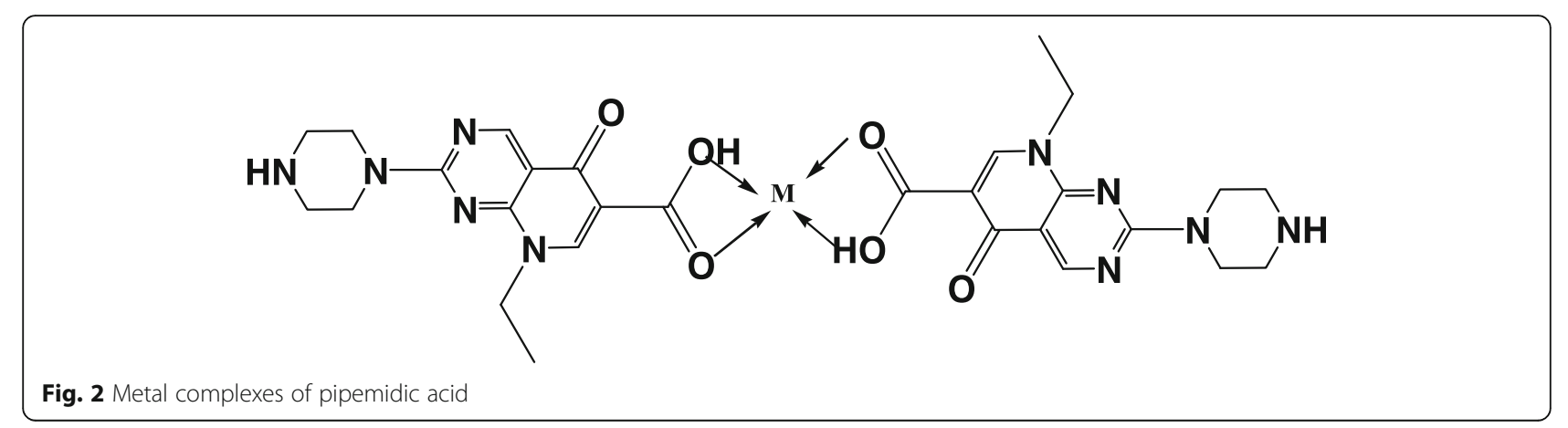


Table 4 Elemental analysis and metal estimation of pipemidic acid and its metal complexes

\begin{tabular}{lllll}
\hline Empirical formula (formula weight) & $\% \mathbf{C}$ & $\% \mathbf{H}$ & $\% \mathbf{N}$ & \%Metal \\
\hline $\mathrm{C}_{28} \mathrm{H}_{34} \mathrm{~N}_{10} \mathrm{O}_{6}(606.64)$ & 55.54 & 5.65 & 23.09 & 0.00 \\
$\mathrm{C}_{28} \mathrm{H}_{34} \mathrm{~N}_{10} \mathrm{O}_{6} \mathrm{Mg}$ & 53.34 & 5.40 & 22.26 & 3.85 \\
$(630.95)$ & $(53.31)$ & $(5.44)$ & $(22.22)$ & $(3.81)$ \\
$\mathrm{C}_{28} \mathrm{H}_{34} \mathrm{~N}_{10} \mathrm{O}_{6} \mathrm{Ca}$ & 52.05 & 5.26 & 21.73 & 6.21 \\
$(646.72)$ & $(51.99)$ & $(5.30)$ & $(21.67)$ & $(6.18)$ \\
$\mathrm{C}_{28} \mathrm{H}_{34} \mathrm{~N}_{10} \mathrm{O}_{6} \mathrm{Cr}$ & 51.11 & 5.23 & 21.35 & 7.88 \\
$(658.64)$ & $(51.06)$ & $(5.20)$ & $(21.27)$ & $(7.89)$ \\
$\mathrm{C}_{28} \mathrm{H}_{34} \mathrm{~N}_{10} \mathrm{O}_{6} \mathrm{Mn}$ & 50.79 & 5.22 & 21.21 & 8.31 \\
$(661.58)$ & $(50.83)$ & $(5.18)$ & $(21.17)$ & $(8.30)$ \\
$\mathrm{C}_{28} \mathrm{H}_{34} \mathrm{~N}_{10} \mathrm{O}_{6} \mathrm{Fe}$ & 50.80 & 5.23 & 21.20 & 8.43 \\
$(662.49)$ & $(50.76)$ & $(5.17)$ & $(21.14)$ & $(8.43)$ \\
$\mathrm{C}_{28} \mathrm{H}_{34} \mathrm{~N}_{10} \mathrm{O}_{6} \mathrm{Co}$ & 50.50 & 5.20 & 21.06 & 8.88 \\
$(665.57)$ & $(50.53)$ & $(5.15)$ & $(21.04)$ & $(8.85)$ \\
$\mathrm{C}_{28} \mathrm{H}_{34} \mathrm{~N}_{10} \mathrm{O}_{6} \mathrm{Ni}$ & 50.65 & 5.19 & 21.01 & 8.83 \\
$(665.33)$ & $(50.55)$ & $(5.15)$ & $(21.05)$ & $(8.82)$ \\
$\mathrm{C}_{28} \mathrm{H}_{34} \mathrm{~N}_{10} \mathrm{O}_{6} \mathrm{Cu}$ & 50.11 & 5.15 & 20.83 & 9.50 \\
$(670.19)$ & $(50.18)$ & $(5.11)$ & $(20.90)$ & $(9.48)$ \\
$\mathrm{C}_{28} \mathrm{H}_{34} \mathrm{~N}_{10} \mathrm{O}_{6} \mathrm{Zn}$ & 50.10 & 5.12 & 20.90 & 9.72 \\
$(672.02)$ & $(50.04)$ & $(5.10)$ & $(20.84)$ & $(9.73)$ \\
$\mathrm{C}_{28} \mathrm{H}_{34} \mathrm{~N}_{10} \mathrm{O}_{6} \mathrm{Cd}$ & 46.71 & 4.74 & 19.53 & 15.62 \\
$(719.05)$ & $(46.77)$ & $(4.77)$ & $(19.48)$ & $(15.63)$ \\
$(E \times p e c t e d)$ & & & & \\
\hline & & & & \\
& & & &
\end{tabular}

whereas in manganese and iron, it occurred as a small peak at 1730 and $1732 \mathrm{~cm}^{-1}$, respectively. The calcium, chromium, and cadmium showed sharp peaks in the region between 1720 and $1735 \mathrm{~cm}^{-1}$.

For the carboxylic ring group, the peaks of all metal complexes shifted towards lower wavenumber that are calcium, chromium, and nickel recorded as a sharp peak in the region of $1610-1619 \mathrm{~cm}^{-1}$, while in magnesium, manganese, iron, cobalt, and cadmium broad bands were obtained in the region $1600-1630 \mathrm{~cm}^{-1}$. Copper and zinc showed medium peaks at 1605 and $1618 \mathrm{~cm}^{-1}$, respectively (Table 2). The formation of the bidentate ligand with metal ion coordinate with the oxygen of carbonyl ring and oxygen of the hydroxyl group is evident from these results [19].

\section{UV/visible spectrophotometric studies}

Pipemidic acid and its metal complexes were dissolved in distilled water and scan in the range of 200 to 700 $\mathrm{nm}$. Both bathochromic and hypsochromic shifts were found in the spectra, with the bands at 268 and $329 \mathrm{~nm}$ shifted to 270 and $327 \mathrm{~nm}$, respectively. A similar type of results obtained in another study. Marija et al. [19] compared the spectra of ciprofloxacin and ciprofloxacin zinc complex in the same solvent, in the presence of zinc ions, and both bathochromic and hypsochromic shifts were found. This proposes the complexation between the drug and metal.

\section{NMR studies}

Table 3 shows the NMR data of pipemidic acid and its metal complexes. The ethyl group peaks of protons were at 1.34 and $2.47 \mathrm{ppm}$ in the standard spectra of pipemidic acid. Peaks of piperazinyl protons were found at 2.77 and $3.33 \mathrm{ppm}$, while the proton of the pyridone ring was at $8.94 \mathrm{ppm}$. Protons of ring adjacent to pyridone were at $3.81 \mathrm{ppm}$ and carboxylic proton at $9.17 \mathrm{ppm}$. In a comparison of main peaks of pipemidic acid with metal complexes, it was concluded that all other groups showed a set of signals that were almost similar except for carboxylic moiety that took part in bonding with metal shown by a downfield of signals indicative of its participation in bonding with a metal ion (supplementary information).

\section{Atomic absorption and elemental analysis studies}

Estimation of pipemidic acid and its complexes were carried out by using the Pye-Unicam atomic absorption spectrometer. The expected percentage of magnesium in pipemidic acid magnesium complex for 1:1 ratio was $6.83 \%$, for $2: 1$ ratio $3.85 \%$, and for $4: 1$ ratio $1.96 \%$ while according to the experimental results, the percentage calculated was $3.86 \%$ which is nearest to the expected value of 2:1 ratio, showing that the drug and metal are bonded in the ratio of 2:1 (Fig. 2). Similar results were obtained in all complexes establishing that the drug and metal are bound together in the ratio of 2:1. Table 4 shows the data of the elemental analysis of the drug metal complex.

\section{Antibacterial activity}

All of these organisms were tested against pipemidic acid metal complexes, and both standard and complexes show no activity against a few microorganisms [18] or similar antibacterial activity against the clinical isolates as compared to the standard drug as reported earlier [12], which illustrates a clear picture that older quinolone is outdated as compared to the new generation of quinolone.

\section{Conclusion}

The differences in the colour, conductance value, and the change in melting points of these complexes suggested that a new product has been formed. The characterization studies of drug and metal complexes included IR, and ${ }^{1} \mathrm{H}-\mathrm{NMR}$ spectroscopic techniques, elemental analysis, and AA spectroscopy suggested the structure of complexes. The shifts in the peaks of the IR 
region as well in the ${ }^{1} \mathrm{H}$-NMR studies confirmed the presence of drug metal complexation. The resulting complexes are showing that the drug and metal are bonded with a 2:1 ratio.

\section{Abbreviations}

IR: Infrared; UV: Ultraviolet; ' ${ }^{H}$-NMR: Hydrogen-nuclear magnetic resonance; CHN analysis: Carbon hydrogen nitrogen analysis

\section{Supplementary Information}

The online version contains supplementary material available at https://doi. org/10.1186/s43094-021-00301-8.

Additional file 1.

\section{Acknowledgements}

Not applicable.

\section{Authors' contributions}

AZS: design, performed the experiment, writing of the project. AZM: help in writing and supervising the project. All authors have read and approved the manuscript.

\section{Funding}

No funding received for this work.

Availability of data and materials

Data and materials are available upon request.

\section{Declarations}

Ethics approval and consent to participate

Not applicable.

\section{Consent for publication}

Not applicable.

\section{Competing interests}

No competing interests have been reported for the manuscript.

\section{Author details}

${ }^{1}$ Research Institute of Pharmaceutical Sciences, Department of

Pharmaceutical Chemistry, Faculty of Pharmacy, University of Karachi, Karachi 75270, Pakistan. ${ }^{2}$ Highnoon Laboratories Limited, Lahore, Pakistan. ${ }^{3}$ Chemistry Department, Faculty of Applied Sciences, Umm Al-Qura University, Makkah, Saudi Arabia.

Received: 31 March 2021 Accepted: 5 July 2021

Published online: 23 July 2021

\section{References}

1. Budavari S. (2001) The Merck Index. Merck \& Co. Inc. Germany. p. 403, 1200, 1266

2. Mroz E, Jankowski S, Bartelmus J, Grzybek-Hryncewicz K, Ruczkowska J, Starek J, Boratynska M (1993) Susceptibility in vitro to certain quinolines of gram-negative bacteria and gram-positive cocci causing urinary tract infections. Med Dosw Mikrobiol. 45(1):115-118

3. Muytjens HL, Veldhuizen GL, Welling GW, Ros-van de Repe J, Boerema HB, Waaij D (1983) Selective decontamination of the digestive tract by pipemidic acid. Antimicrob Agents Chemother. 24(6):902-904. https://doi. org/10.1128/AAC.24.6.902

4. Paula C, Alves PR, Bravo C, Antunes AMM, André V (2020) Bioactivity of isostructural hydrogen bonding frameworks built from pipemidic acid metal complexes. Molecules 25:2374. https://doi.org/10.3390/molecules25102374

5. Harder S (1989) Ciprofloxacin caffeine, a drug interaction established using in vivo and in vitro investigations. Am J Med. 33:474-478
6. Barnett $G$ (1990) Pharmacokinetics determination of relative potency of quinolone inhibition of caffeine disposition. Eur J Clin Pharmacol. 39(1):6369. https://doi.org/10.1007/BF02657060

7. Staib AH (1989) Interaction of quinolones with the theophylline metabolism in man, investigation with lomefloxacin and pipemidic acid. Int J Clin Pharmacol Ther. Toxicol. 27:289-293

8. Duran MI, Munoz de la Pena A, Salinas LF, Rodriguez Caceres MI (2000) Complexation of antibacterial quinolonic acid and cinolonic derivatives with $\mathrm{Zn}(\mathrm{II})$ and $\mathrm{Al}(\mathrm{III)}$ : application to their determination in human urine. Analyst. 125(8):1471-1476

9. Ramotowska S, Wysocka M, Brzeski J, Chylewska A, Makowski M (2020) A comprehensive approach to the analysis of antibiotic-metal complexes. Trends Anal Chem 123:115771. https://doi.org/10.1016/j.trac.2019.115771

10. Lopatkin NA, Trapeznikova MF, Mazo EB, Derevianko II, Sobolevskii AB, Dolzhenok AN, Meshkov W (1997) Urotractin in the treatment of an infection of the kidneys, urinary tract and prostate. Urol Nefrol (Mosk). 5:3-5

11. Lin Y, Li W, Tao D, Li Y, Yang X (1999) Synthesis and characterization of main group metal complexes with pipemidic acid. Synth Reactivity Inorgan Metal-Organic Chem 29(8):1485-1494

12. Eleni K, Efthimiadou YS, Katsaros N, Karaliota A, Psomas G (2007) Transition metal complexes with the quinolone antibacterial agent pipemidic acid: synthesis, characterization and biological activity. Polyhedron 26:1148-1158

13. Sultana N, Arayne MS, Siddiqi AZ, Mirza AZ (2019) Synthesis and antibacterial studies of ciprofloxacin-metal complexes. J Chinese Pharm Sci 28(6):422-429

14. Arayne MS, Sultana N, Mirza AZ (2009) Preparation and spectroscopic characterization of metal complexes of gliquidone. J Mol Struct 927(1-3):5459. https://doi.org/10.1016/j.molstruc.2009.02.020

15. Bauer AW, Kirby WMM, Sherris JC, Turck M (1966) Antibiotic susceptibility testing by a standardized single disk method. Am J Clin Pathol. 45(4 ts): 493-496. https://doi.org/10.1093/ajcp/45.4_ts.493

16. National Committee on Clinical Laboratory Standards. (1983). Performance standards for antimicrobial disk susceptibility tests, vol 3 (14). Villanova

17. Alibrahim KA, Al-Saif FA, Alghamdi MT, El-Shahawi MS, Moustafa YM, Refat MS (2018) Synthesis, spectroscopic, thermal, antimicrobial and electrochemical characterization of some novel Ru(III), Pt(IV) and Ir(III) complexes of pipemidic acid. RSC Adv 8:22515-22529. https://doi.org/10.1 039/C8RA03879A

18. Lin Y, Dongliang T, Xialoi Y, Yongfang L, Yuming G (2003) Synthesis, characterization and antibacterial activities of some rare earth metal complexes of pipemidic acid. Chem Pharm Bull. 51(5):494-498

19. Marija Z, Iztok T, Peter B, Andrew JPW, David JW (2001) Synthesis and characterization of two novel zinc (II) complexes with ciprofloxacin, Crystal structure of $\left[\mathrm{C}_{17} \mathrm{H}_{19} \mathrm{~N}_{1} \mathrm{O}_{3} \mathrm{~F}_{2} \cdot\left[\mathrm{ZnCl}_{4}\right] .2 \mathrm{H}_{2} \mathrm{O}\right.$. Croatica Chemica Acta 74(1):61-74

\section{Publisher's Note}

Springer Nature remains neutral with regard to jurisdictional claims in published maps and institutional affiliations.

\section{Submit your manuscript to a SpringerOpen ${ }^{\circ}$ journal and benefit from:}

- Convenient online submission

- Rigorous peer review

- Open access: articles freely available online

High visibility within the field

- Retaining the copyright to your article

Submit your next manuscript at $>$ springeropen.com 